\title{
Perbandingan Metode Segmentasi K-Means Clustering dan Segmentasi Region Growing untuk Pengukuran Luas Wilayah Hutan Mangrove
}

\section{Comparison of K-Means Clustering and Growing Region Segmentation Methods for Area Measurement of Mangrove Forests}

\author{
Tyas Panorama Nan Cerah, Oky Dwi Nurhayati*), R. Rizal Isnanto \\ Departemen Teknik Komputer, Fakultas Teknik, Universitas Diponegoro \\ Jl. Prof. Soedarto, SH, Kampus Undip Tembalang, Semarang, Indonesia 50275
}

\begin{abstract}
Cara sitasi: T. P. N. Cerah, O. D. Nurhayati, and R. R. Isnanto, "Perbandingan Metode Segmentasi K-Means Clustering dan Segmentasi Region Growing untuk Pengukuran Luas Wilayah Hutan Mangrove," Jurnal Teknologi dan Sistem Komputer, vol. 7, no. 1, 2019. doi: 10.14710/jtsiskom.7.1.2019.31-37, [Online].
\end{abstract}

\begin{abstract}
This study aims to examine the k-means clustering and region growing segmentation methods to identify and measure the area of mangrove forests in the Southeast Sulawesi province. The image of the area of this study used Landsat 8 satellite imagery. The area of mangrove forest was carried out by calculating the number of pixels identified as mangrove forests with an area density of $900 \mathrm{m2}$ /pixel. The accuracy of the two segmentation methods in calculating the area was compared based on the same area calculated by LAPAN. The overall accuracy of $k$ means clustering segmentation method has better accuracy, which is $59.26 \%$, than region growing with $33.33 \%$ of accuracy. Both image segmentation methods, $k$-means clustering and region growing, can be used to calculate the area of mangrove forests in the Southeast Sulawesi region using Landsat 8 satellite imagery.
\end{abstract}

Keywords - mangrove forest area; digital image processing; k-means clustering; region growing; satellite imagery segmentation

Abstrak - Penelitian ini bertujuan mengkaji metode
segmentasi k-means clustering dan region growing
untuk mengidentifikasi dan mengukur luas hutan
mangrove di wilayah provinsi Sulawesi Tenggara.
Citra daerah yang dikaji menggunakan citra satelit
Landsat 8 . Luas wilayah hutan mangrove dilakukan
dengan menghitung jumlah piksel yang diidentifikasi
sebagai hutan mangrove dengan densitas luas area
900 m $^{2}$ perpiksel. Akurasi kedua metode segmentasi
dalam pengukuran luas daerah dibandingkan
berdasarkan luas daerah dari LAPAN. Metode
segmentasi k-means clustering secara keseluruhan
mempunyai akurasi perhitungan luas yang lebih
akuras sebesr 59,26\% dibandingkan region growing
sebesar 33,33\%. Kedua metode segmentasi citra, baik
k-means clustering maupun region growing, dapat

${ }^{*}$ Penulis korespondensi (Oky Dwi Nurhayati)

Email: okydwi.n@gmail.com digunakan untuk menghitung luas hutan mangrove yang ada di wilayah Sulawesi Tenggara dengan menggunakan data citra satelit Landsat 8.

Kata-kunci - luas hutan mangrove; pengolahan citra digital; k-means clustering; region growing; segmentasi citra satelit

\section{Pendahuluan}

Hutan mangrove adalah tipe hutan yang khas yang hidup di sepanjang pantai atau muara sungai yang dipengaruhi oleh pasang surut air laut dengan rentang salinitas yang tinggi. Hutan mangrove dapat tumbuh pada pantai karang, yaitu pada karang koral mati yang di atasnya ditumbuhi selapis tipis pasir atau ditumbuhi lumpur atau pasir berlumpur. Mangrove tidak tumbuh di pantai yang terjal dan berombak besar dengan arus pasang surut yang kuat karena hal tersebut tidak memungkinkan terjadinya pengendapan lumpur dan pasir sebagai substrat yang diperlukan untuk pertumbuhan mangrove [1]. Luas ekosistem mangrove di Indonesia mencapai $75 \%$ dari total mangrove di Asia Tenggara atau sekitar $27 \%$ dari luas mangrove di dunia. Saat ini, tercatat Indonesia mempunyai hutan mangrove seluas 9,36 juta hektar yang tersebar di seluruh Indonesia. Namun, keberadaan hutan mangrove di Indonesia kian terancam yang disebabkan oleh banyaknya pemanfaatan lahan yang tidak terkontrol karena tingginya ketergantungan masyarakat yang menempati wilayah pesisir [2]. Identifikasi keberadaan hutan mangrove perlu dilakukan.

Pengolahan citra satelit telah banyak digunakan untuk mengidentifikasi dan menganalisis perubahan bentuk, luas, ataupun kondisi lainnya dari suatu wilayah. Citra satelit yang digunakan salah satunya adalah dari citra Landsat 8 [3]-[6]. Citra Landsat 8 ini telah digunakan dalam pengolahan untuk mengidentifikasi dan menghitung luas hutan mangrove [4], [5] dan luas daerah di pulau-pulau kecil [6].

Salah satu metode yang digunakan untuk identifikasi adalah dengan segmentasi citra menjadi wilayah- 
Tabel 1. Karakteristik kanal citra Landsat 8 [3]

\begin{tabular}{|c|c|c|}
\hline Kanal & $\begin{array}{c}\text { Panjang } \\
\text { Gelombang } \\
(\mu \mathrm{m})\end{array}$ & Keterangan \\
\hline 1 - aerosol pesisir & $0.43-0.45$ & $\begin{array}{l}\text { Studi aerosol } \\
\text { wilayah pesisir }\end{array}$ \\
\hline 2 - biru & $0.45-0.51$ & $\begin{array}{l}\text { Pemetaan bathimetrik, } \\
\text { membedakan tanah dari vegetasi } \\
\text { dan daun dari vegetasi conifer }\end{array}$ \\
\hline 3 - hijau & $0.53-0.59$ & $\begin{array}{l}\text { Mempertegas puncak vegetasi } \\
\text { untuk menilai kekuatan vegetasi }\end{array}$ \\
\hline 4 - merah & $0.64-0.67$ & Membedakan sudut vegetasi \\
\hline $\begin{array}{l}5 \text { - Infra Merah } \\
\text { Dekat-Near Infrared } \\
\text { (NIR) }\end{array}$ & $0.85-0.88$ & $\begin{array}{l}\text { Menekankan konten biomassa } \\
\text { dan garis pantai }\end{array}$ \\
\hline $\begin{array}{l}\text { 6-Short-Wave } \\
\text { Infrared (SWIR 1) }\end{array}$ & $1.57-1.65$ & $\begin{array}{l}\text { Mendiskriminasikan kadar air } \\
\text { tanah dan vegetasi; menembus } \\
\text { awan tipis }\end{array}$ \\
\hline $\begin{array}{l}\text { 7-Short - Wave } \\
\text { Infrared (SWIR 2) }\end{array}$ & $2.11-2.29$ & $\begin{array}{l}\text { Peningkatan kadar air tanah dan } \\
\text { vegetasi dan penetrasi awan tipis }\end{array}$ \\
\hline 8 - Pankromatic & $0.50-0.68$ & Resolusi 15 m, penajaman citra \\
\hline $9-$ Sirus & $1.36-1.68$ & $\begin{array}{l}\text { Peningkatan deteksi awan sirus } \\
\text { yang terkontaminasi }\end{array}$ \\
\hline $\begin{array}{l}10-\text { Thermal } \\
\text { Infrared Sensor } 1 \\
\text { (TIRS 1) }\end{array}$ & $10.60-11.19$ & $\begin{array}{l}\text { Resolusi } 100 \mathrm{~m} \text {, pemetaan suhu } \\
\text { dan penghitungan kelembaban } \\
\text { tanah }\end{array}$ \\
\hline $\begin{array}{l}11-\text { Thermal } \\
\text { Infrared Sensor } 2 \\
\text { (TIRS 2) }\end{array}$ & $11.5-12.51$ & $\begin{array}{l}\text { Resolusi } 100 \mathrm{~m} \text {, peningkatan } \\
\text { pemetaan suhu } \\
\text { penghitungan } \\
\text { tanah }\end{array}$ \\
\hline
\end{tabular}

wilayah homogen berdasarkan kriteria keserupaan yang tertentu, seperti halnya dalam [7]-[11]. Metode segmentasi di antaranya adalah $k$-means clustering seperti dalam [8], [9] dan region growing seperti dalam [10], [11]. Segmentasi $k$-means clustering membagi sejumlah objek ke dalam partisi-partisi berdasarkan kategori yang ada dengan melihat titik tengah yang diberikan, sedangkan segmentasi region growing dimulai dari piksel seed dan berkembang hingga membentuk wilayah. Segmentasi k-means clustering dalam [8] mampu menghilangkan noise citra, sedangkan region growing dalam [9] tidak mampu. Walau kedua metode memiliki karateristik yang berbeda, segmentasi $k$-means clustering dan region growing memiliki beberapa persamaan. Salah satunya adalah dalam menentukan suatu piksel menjadi wilayah atau kelompok, yaitu dengan satu titik pusat dan membentuk wilayah dengan ketentuan atau properti tertentu, yaitu jarak terdekat antar-piksel.

Penghitungan luas hutan mangrove dalam [4] dan [5] tidak menggunakan segmentasi citra menggunakan $k$-means clustering dan region growing. Kajian ini bertujuan mengimplementasikan dan menganalisis metode segmentasi k-means clustering dan region growing untuk mengukur luas wilayah hutan mangrove menggunakan citra Landsat 8 dengan menghitung jumlah piksel yang teridentifikasi sebagai daerah hutan mangrove. Akurasi kedua metode dihitung menggunakan referensi data luas hutan mangrove dari LAPAN [12].

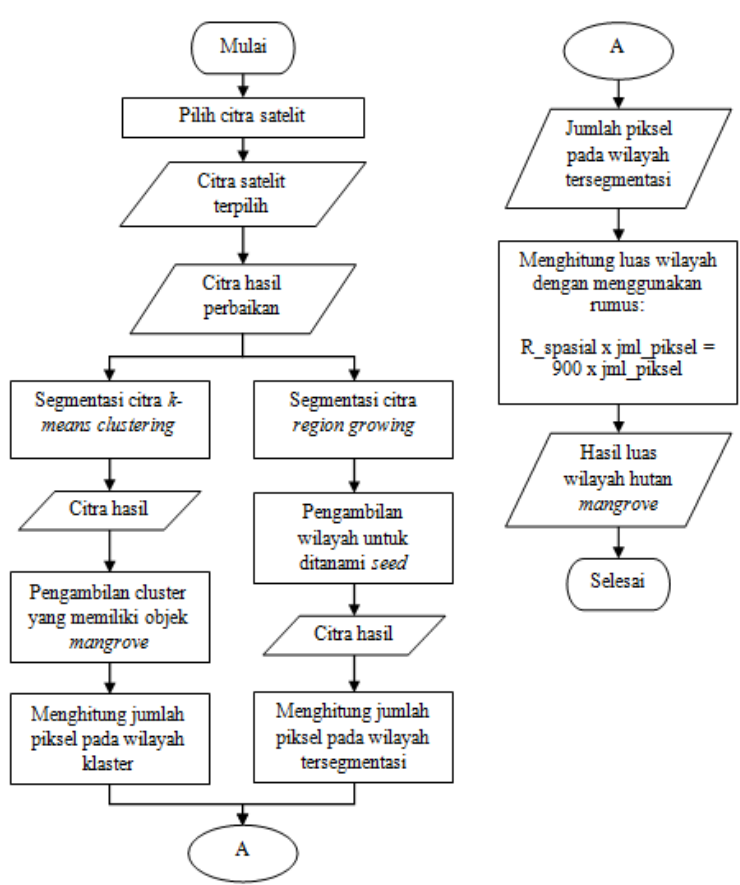

Gambar 1. Diagram alir sistem penghitung luas wilayah hutan mangrove

\section{Metode Penelitian}

Data yang digunakan untuk mengidentifikasi hutan mangrove adalah data citra satelit Landsat 8 OLI/TIRS dari Provinsi Sulawesi Tenggara, meliputi Kabupaten Bombana, Kabupaten Buton Utara, Kabupaten Kolaka, Kabupaten Konawe, Kabupaten Konawe Selatan, dan Kabupaten Muna. Data diperoleh secara gratis pada website resmi USGS Earth Explorer (https://earthexplorer.usgs.gov/). Dari data satelit yang diperoleh, dipilih kombinasi kanal 5, 6, dan 3 untuk mengidentifikasi objek hutan mangrove. Karakteristik kanal citra Landsat 8 secara lengkap dinyatakan dalam Tabel 1. Data satelit yang telah jelas objeknya dilakukan koreksi radiometrik dan koreksi geometrik sehingga diperoleh citra satelit yang telah terkoreksi yang selanjutnya diolah oleh sistem. Citra masukan memiliki ukuran antara 109x113 piksel sampai dengan 505x519 piksel, dengan jumlah data masukan berjumlah 27 gambar dengan ekstensi jpg.

Diagram alir sistem penggitung luas wilayah hutan mangrove ditunjukkan oleh Gambar 1. Perbaikan citra meliputi enam tahap, yaitu penggabungan kanal citra satelit, koreksi radiometrik, koreksi geometrik, pemilihan kombinasi kanal, penggabungan citra satelit, dan pemotongan citra pada bagian objek mangrove. Perhitungan luas wilayah dilakukan dengan mengetahui jumlah piksel wilayah hutan mangrove yang telah dinyatakan dengan intensitas warna yang sama dengan menggunakan segmentasi citra. Jumlah piksel tersebut kemudian dikalikan dengan satuan luas per-piksel menggunakan resolusi spasial dari Landsat 8 untuk semua kanal,yaitu sebesar 30 × $30 \mathrm{~m}^{2}$ untuk tiap piksel. 


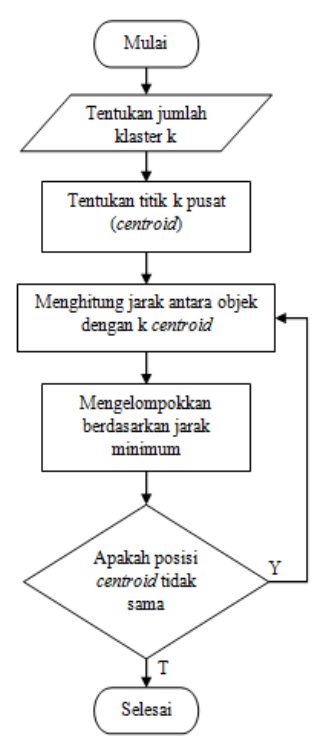

(a)

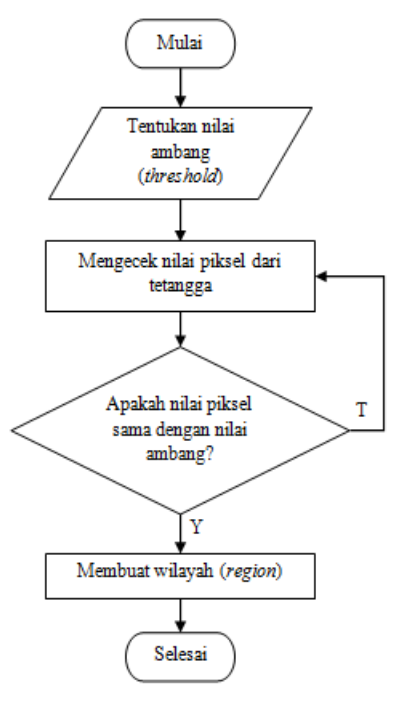

(b)
Gambar 2. Alir proses segmentasi pada citra: a) $k$ means clustering, dan b) region growing

Diagram alir metode segmentasi $k$-means clustering dan region growing ditunjukkan dalam Gambar 2. Pada segmentasi k-means clustering, proses klastering dimulai dengan mengidentifikasi data yang akan diklaster, $\quad c_{i j}(i=1, \ldots, n ; j=1, \ldots, m)$ dengan $n$ adalah jumlah data yang akan diklaster dan $m$ adalah jumlah variabel (Gambar 2a). Pada awal iterasi, pusat setiap klaster ditetapkan secara bebas, $c_{k j}(k=1, \ldots, k ; j=1, \ldots, m)$. Jarak antara setiap data dengan setiap pusat klaster dihitung. Untuk melakukan penghitungan jarak data ke-i $\left(c_{i}\right)$ pada pusat klaster ke$\mathrm{k}\left(c_{k}\right)$, diberi nama $\left(d_{i k}\right)$. Persamaan jarak euclidean digunakan seperti dinyatakan dalam Persamaan 1.

$$
d_{i k}=\sqrt{\sum_{j=1}^{m}\left(c_{i j}-c_{k j}\right)^{2}}
$$

Suatu data akan menjadi anggota dari klaster ke-k apabila jarak data tersebut ke pusat klaster ke-k bernilai paling kecil dibandingkan dengan jarak ke pusat klaster lainnya. Hal ini dapat dihitung dengan menggunakan Persamaan 2. Selanjutnya, kelompokkan data-data yang menjadi anggota pada setiap klaster. Nilai pusat klaster yang baru dapat dihitung dengan cara mencari nilai ratarata dari data-data yang menjadi anggota pada klaster tersebut dengan menggunakan Persamaan 3, dimana $x_{i j}$ adalah klaster ke-k dan $p$ adalah banyaknya anggota klaster ke-k.

$$
\min \sum_{k=1}^{k} d_{i k}=\sqrt{\sum_{j=1}^{m}\left(c_{i j}-c_{k j}\right)^{2}}
$$

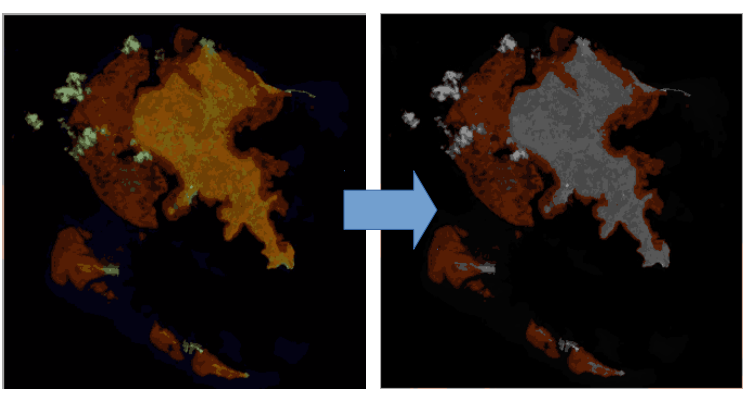

Gambar 3. Hasil akhir dari proses segmentasi k-means clustering

$$
c_{k j}=\frac{\sum_{i=1}^{p} x_{i j}}{p}
$$

Segmentasi dengan metode region growing mengelompokkan piksel atau subwilayah ke dalam wilayah yang lebih besar berdasarkan pada kriteria yang sudah ditentukan untuk pertumbuhannya (Gambar 2b). Pendekatan dasarnya adalah memulai dengan sejumlah titik seed dan dari titik ini menumbuhkan wilayah oleh penambahan pada setiap seed piksel tetangga yang mempunyai property sama dengan seed (seperti kisaran spesifik dari aras keabuan atau warna). Penumbuhan wilayah akan berhenti ketika tidak ada lagi piksel yang mencapai kriteria untuk inklusi dalam wilayah tersebut. Metode region growing tidak menggunakan kriteria lokal, seperti intensitas, tekstur, dan warna [13].

\section{Hasil dan PEMbahasan}

\section{A. Proses Segmentasi dengan K-Means Clustering}

Proses segmentasi dilakukan dengan mengelompokkan citra menjadi beberapa kelompok atau klaster secara acak berdasarkan histogram. Jarak piksel ditentukan dengan centroid (titik tengah klaster). Jarak minimal piksel dengan centroid kemudian ditentukan sehingga terbentuklah kelompok-kelompok berdasarkan nilai minimum piksel dengan centroid. Dari kelompok tersebut dilakukan penghitungan rerata dari setiap anggota dari satu klaster. Dari nilai rerata setiap klaster tersebut, didapatkan nilai centroid baru. Dengan nilai centroid baru ini proses diulang sampai nilai rerata dari anggota klaster tidak lagi mengalami perubahan.

Hasil dari proses segmentasi adalah citra yang telah terkelompokkan sesuai dengan nilai jumlah klaster (antara 2 sampai 20 klaster). Dari hasil segmentasi, dilakukan tahap penghitungan luas wilayah hutan mangrove. Pengambilan objek mangrove dilakukan dengan teknik penutupan objek dengan hanya menampilkan objek yang diinginkan (masking) menggunakan metode pengambangan dengan ruang warna HSV sebagai acuan. Cara kerjanya adalah dengan menentukan nilai minimal dan nilai maksimal dari setiap kanal pada ruang warna HSV. Dari nilai minimal 


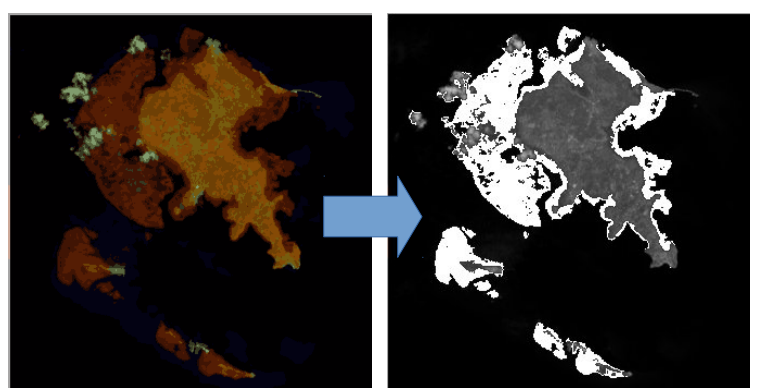

Gambar 4. Hasil akhir dari proses segmentasi region growing

dan maksimal yang telah ditentukan, diloloskan gambar klaster yang memiliki kecocokan nilai dari citra hasil segmentasi sebelumnya. Objek mangrove memiliki warna yang sama dengan hasil segmentasi $k$-means clustering pada proses sebelumnya dan objek nonmangrove ditampilkan dengan warna aras keabuan. Hasil proses segmentasi k-means clustering ditunjukkan dalam Gambar 3.

\section{B. Proses Segmentasi dengan Region Growing}

Proses pertama segmentasi region growing adalah penentuan nilai intensitas untuk dijadikan nilai seed. Agar nilai seed dan nilai ambang dapat terimplementasi secara automatis pada lebih dari satu citra satelit, dilakukan pembandingan histogram pada masingmasing citra satelit agar dapat dicari kesamaannya. Pembandingan kesamaan histogram pada citra satelit ditemukan kesamaan dimulai dari intensitas 0 yang memiliki jumlah piksel yang relatif banyak. Seiring bertambahnya nilai intensitas, jumlah piksel yang sama semakin menurun dan berhenti pada nilai intensitas kurang lebih 10 dan relatif stabil sampai nilai intensitas kurang lebih 35.

Pada pengujian, nilai intensitas mangrove ada yang bernilai lebih dari 35 . Untuk menanggulangi masalah ini, dilakukan penyamaan intensitas dari nilai 45 sampai dengan 55 menjadi nilai 35 sehingga nilai seed yang digunakan adalah 35 dan nilai ambang adalah 10 untuk menentukan batas nilai intensitas. Dari hasil segmentasi region growing dilakukan pengubahan nilai intensitas untuk menjadikan nilai pada hasil segmentasi menjadi 1 apabila mempunyai nilai intensitas lebih dari 1 dan bernilai 0 jika nilai intensitas kurang dari 1 .

Dari nilai seed dan nilai ambang yang telah ditentukan, diperoleh hasil citra hasil segmentasi berbentuk citra biner dengan daerah mangrove yang memiliki nilai 1 , dan daerah bukan mangrove memiliki nilai 0 (Gambar 4). Dari citra hasil segmentasi dilakukan penggabungan citra awal dengan citra segmentasi agar diperoleh gambar objek mangrove dan objek bukan mangrove yang jelas.

\section{Proses Operasi Penghitung Luas Mangrove}

Proses ini menghitung luas daerah mangrove berdasarkan jumlah piksel yang telah diperoleh. Proses penghitungan jumlah wilayah dilakukan dengan menjumlahkan nilai 1 pada citra tersegmentasi, yaitu citra yang memiliki objek mangrove. Setiap piksel mewakili luasan mangrove sebesar $900 \mathrm{~m}^{2}$. Luas pembanding pada daerah yang sama dari data luas mangrove LAPAN [12].

Hasil penghitungan luas daerah mangrove di wilayah Sulawesi Tenggara menggunakan segmentasi k-means clustering ditunjukkan dalam Tabel 2. Jumlah klaster yang ditampilkan adalah 11, 12, dan 13. Jumlah klaster ini mempunyai kemiripan data dengan data yang didapatkan di LAPAN. Hasil penghitungan luas daerah mangrove menggunakan segmentasi region growing ditunjukkan dalam Tabel 3.

\section{Perbandingan Akurasi Metode Segmentasi}

Akurasi metode segmentasi untuk menghitung luas hutan mangrove dinyatakan sebagai akurasi bobot pada setiap citra (Persamaan 4) dan akurasi data yang benar secara keseluruhan dari kedua metode segmentasi (Persamaan 5). Parameter $\mathrm{N}_{\text {hasil }}$ menyatakan luas mangrove hasil penghitungan metode, sedangkan $\mathrm{N}_{\text {ref }}$ menyatakan luas pembanding. Parameter Ndata benar menyatakan jumlah identifikasi citra mangrove yang mempunyai akurasi di atas $80 \%$, sedangkan Ndata total menyatakan jumlah citra yang diidentifikasi, yaitu sebesar 27 citra. Akurasi keseluruhan ini menunjukkan persentase identifikasi citra yang mempunyai akurasi lebih dari $80 \%$ terhadap jumlah citra yang digunakan dalam identfifikasi.

$$
\begin{gathered}
\text { Akurasibobot }=100-\left(\left|\frac{N_{\text {hasil }}-N_{\text {ref }}}{N_{\text {ref }}}\right|\right) \times 100 \% \\
\text { Akurasi total }=\frac{N_{\text {databenar }}}{N_{\text {datatotal }}} \times 100 \%
\end{gathered}
$$

Akurasi penghitungan luas hutan mangrove menggunakan metode segmentasi region growing dan k-means clustering ditunjukkan dalam Tabel 4. Akurasi terbesar dalam segmentasi $k$-means clustering adalah 98,81\% (dengan 11 klaster), 99,03\% (dengan 12 klaster), dan 98,24\% (dengan 13 klaster). Hal ini tidak terdapat korelasi antara jumlah klaster dengan akurasi yang diperoleh. Akurasi yang tinggi menunjukkan bahwa k-means clustering dapat digunakan sebagai metode segmentasi dalam identifikasi daerah mangrove, seperti halnya dalam [8], [9]. Akurasi terbesar dalam segmentasi region growing adalah 99,90\%. Hal ini juga menunjukkan bahwa region growing dapat digunakan sebagai metode segmentasi dalam identifikasi daerah mangrove, seperti halnya dalam [10], [11].

Dari seluruh deteksi yang dilakukan terhadap 27 citra, akurasi keseluruhan berurutan dari yang tertinggi adalah menggunakan 12 klaster sebesar 59,26\%, 13 klaster sebesar 51,85\%, dan 11 klaster sebesar 44,44\%. Akurasi keseluruhan metode region growing dari 27 citra adalah sebesar 33,33\% dan lebih rendah daripada metode k-means clustering. Hal ini menunjukkan bahwa 
Tabel 2. Hasil penghitungan pada citra satelit pada segmentasi $k$-means clustering

\begin{tabular}{|c|c|c|c|c|c|c|c|c|}
\hline \multirow[b]{3}{*}{ No } & \multirow[b]{3}{*}{ Nama Citra } & \multicolumn{6}{|c|}{ Jumlah klaster } & \multirow{3}{*}{$\begin{array}{c}\text { Luas } \\
\text { pembanding } \\
\text { (ha) }\end{array}$} \\
\hline & & \multicolumn{2}{|c|}{11} & \multicolumn{2}{|c|}{12} & \multicolumn{2}{|c|}{13} & \\
\hline & & $\begin{array}{c}\text { Jumlah } \\
\text { piksel }\end{array}$ & $\begin{array}{l}\text { Luas } \\
\text { mangrove } \\
\text { (ha) }\end{array}$ & $\begin{array}{c}\text { Jumlah } \\
\text { piksel }\end{array}$ & $\begin{array}{l}\text { Luas } \\
\text { mangrove } \\
\text { (ha) }\end{array}$ & $\begin{array}{c}\text { Jumlah } \\
\text { piksel }\end{array}$ & $\begin{array}{l}\text { Luas } \\
\text { mangrove } \\
\text { (ha) }\end{array}$ & \\
\hline 1 & Peta Mangrove P. Kabaena 1 & 6.823 & 614,070 & 6.841 & 615,690 & 8.186 & 736,740 & 716,56 \\
\hline 2 & Peta Mangrove P. Kabaena 2 & 2.218 & 199,620 & 2.148 & 193,320 & 1.829 & 164,610 & 168 \\
\hline 3 & Peta Mangrove Konawe 1 & 6.314 & 568,260 & 6.249 & 562,410 & 9.459 & 851,310 & 557 \\
\hline 4 & Peta Mangrove Konawe 2 & 48.743 & $4.386,870$ & 49.398 & $4.445,820$ & 48.294 & $4.346,460$ & $5.803,83$ \\
\hline 5 & Peta Mangrove Konawe 3 & - & - & 7.197 & 647,730 & 7.125 & 641,250 & 814,34 \\
\hline 6 & Peta Mangrove Konawe 4 & 8.907 & 801,630 & 8.765 & 788,850 & 5.860 & 527,400 & 1.448 \\
\hline 7 & Peta Mangrove Konawe 5 & 7.385 & 664,650 & 7.351 & 661,590 & 7.331 & 659,790 & 1.313 \\
\hline 8 & Peta Mangrove Konawe 6 & 1.451 & 130,590 & 2.387 & 214,830 & 1.444 & 129,960 & $1.185,77$ \\
\hline 9 & Peta Mangrove Konawe 7 & - & - & - & - & - & - & 526,02 \\
\hline 10 & Peta Mangrove Kolaka 1 & - & - & 2.452 & 220,680 & 2.261 & 203,490 & 266,65 \\
\hline 11 & Peta Mangrove Buton Utara 1 & 4.347 & 391,230 & 4.334 & 390,060 & 3.612 & 325,080 & 450 \\
\hline 12 & Peta Mangrove Buton Utara 2 & 10.348 & 931,320 & 10.150 & 913,500 & 9.802 & 882,180 & $1.039,15$ \\
\hline 13 & Peta Mangrove Buton Utara 3 & 9.247 & 832,230 & 14.906 & $1.341,540$ & 14.749 & $1.327,410$ & 1.213 \\
\hline 14 & Peta Mangrove Buton Utara 4 & 14.380 & $1.294,200$ & 13.503 & $1.215,270$ & 12.657 & $1.139,130$ & 1.279 \\
\hline 15 & Peta Mangrove Buton Utara 5 & 10.989 & 989,010 & 10.903 & 981,270 & 6.882 & 619,380 & 1.053 \\
\hline 16 & Peta Mangrove Buton Utara 6 & 36.957 & $3.326,130$ & 31.897 & $2.870,730$ & 32.526 & $2.927,340$ & $3.604,19$ \\
\hline 17 & Peta Mangrove Buton Utara 7 & 22.774 & $2.049,660$ & 38.502 & $3.465,180$ & 28.279 & $2.545,110$ & 5.687 \\
\hline 18 & Peta Mangrove Buton Utara 8 & 1.650 & 148,500 & 1.784 & 160,560 & 1.776 & 159,840 & 819 \\
\hline 19 & Peta Mangrove Muna 1 & 14.328 & $1.289,520$ & 16.085 & $1.447,650$ & 15.962 & $1.436,580$ & $1.350,77$ \\
\hline 20 & Peta Mangrove Muna 2 & 12.056 & $1.085,040$ & 12.005 & $1.080,450$ & 11.914 & $1.072,260$ & $1.205,85$ \\
\hline 21 & Peta Mangrove Muna 3 & 1.852 & 166,680 & 2.747 & 247,230 & 2.729 & 245,610 & 251,26 \\
\hline 22 & Peta Mangrove Muna 4 & 1.475 & 132,750 & 1.422 & 127,980 & 2.276 & 204,840 & 208,51 \\
\hline 23 & Peta Mangrove Muna 5 & 5.508 & 495,720 & 5.506 & 495,540 & 5.465 & 491,850 & 471 \\
\hline 24 & Peta Mangrove Muna 6 & 6.195 & 557,550 & 8.911 & 801,990 & 8.834 & 795,060 & 846 \\
\hline 25 & Peta Mangrove Muna 7 & 3.141 & 282,690 & 3.136 & 282,240 & 3.064 & 275,760 & 317 \\
\hline 26 & Peta Mangrove Muna 8 & 2.078 & 187,020 & 1.950 & 175,500 & 1.888 & 169,920 & 236 \\
\hline 27 & Peta Mangrove Muna 9 & 3.769 & 339,210 & 3.304 & 297,360 & 3.214 & 289,260 & 257 \\
\hline
\end{tabular}

Tabel 3. Hasil penghitungan pada citra satelit pada segmentasi region growing

\begin{tabular}{clccc}
\hline No & \multicolumn{1}{c}{ Nama Citra } & Jumlah piksel & Luas mangrove (ha) & Luas pembanding (ha) \\
\hline 1 & Peta Mangrove Pulau Kabaena 1 & 8.210 & 738,9 & 716,56 \\
2 & Peta Mangrove Pulau Kabaena 2 & 185 & 16,65 & 168 \\
3 & Peta Mangrove Konawe 1 & 10.315 & 928,35 & 557 \\
4 & Peta Mangrove Konawe 2 & 49.245 & $4.432,05$ & $5.803,83$ \\
5 & Peta Mangrove Konawe 3 & 15.407 & $1.386,63$ & 814,34 \\
6 & Peta Mangrove Konawe 4 & 11.954 & $1.075,86$ & 1.448 \\
7 & Peta Mangrove Konawe 5 & 9.940 & 1.313 \\
8 & Peta Mangrove Konawe 6 & 1.910 & 171,6 & $1.185,77$ \\
9 & Peta Mangrove Konawe 7 & 3.830 & 344,7 & 526,02 \\
10 & Peta Mangrove Kolaka 1 & 2.678 & 266,65 \\
11 & Peta Mangrove Buton Utara 1 & 3.820 & 34,02 & 450 \\
12 & Peta Mangrove Buton Utara 2 & 8.860 & 793,8 & $1.039,15$ \\
13 & Peta Mangrove Buton Utara 3 & 2.699 & 1.213 \\
14 & Peta Mangrove Buton Utara 4 & 11.028 & 1.279 \\
15 & Peta Mangrove Buton Utara 5 & 8.305 & 1.053 \\
16 & Peta Mangrove Buton Utara 6 & 36.657 & 992,91 & $3.604,19$ \\
17 & Peta Mangrove Buton Utara 7 & 24.264 & 5.687 \\
18 & Peta Mangrove Buton Utara 8 & 2.663 & $2.299,13$ & 819 \\
19 & Peta Mangrove Muna 1 & 14.049 & 239,67 & $1.350,77$ \\
20 & Peta Mangrove Muna 2 & 10.798 & $1.264,41$ & $1.205,85$ \\
21 & Peta Mangrove Muna 3 & 2.789 & 971,82 & 251,26 \\
22 & Peta Mangrove Muna 4 & 2.950 & 251,01 & 208,51 \\
23 & Peta Mangrove Muna 5 & 4.613 & 265,5 & 471 \\
24 & Peta Mangrove Muna 6 & 7.095 & 415,17 & 846 \\
25 & Peta Mangrove Muna 7 & 2.755 & 247,55 & 317 \\
26 & Peta Mangrove Muna 8 & 2.412 & 217,08 & 236 \\
27 & Peta Mangrove Muna 9 & 2.726 & 257
\end{tabular}


Tabel 4. Tingkat akurasi segmentasi $k$-means clustering dan region growing

\begin{tabular}{|c|c|c|c|c|c|}
\hline \multirow[t]{2}{*}{ No } & \multirow[t]{2}{*}{ Nama Citra } & \multicolumn{3}{|c|}{ k-means clustering } & \multirow{2}{*}{$\begin{array}{c}\text { region growing } \\
\text { Akurasi Setiap Citra } \\
\text { (\%) }\end{array}$} \\
\hline & & 11 & 12 & 13 & \\
\hline 1 & Peta Mangrove P. Kabaena 1 & 85,70 & 85,92 & 97,18 & 96,88 \\
\hline 2 & Peta Mangrove P. Kabaena 2 & 81,18 & 84,93 & 97,98 & 9,91 \\
\hline 3 & Peta Mangrove Konawe 1 & 97,98 & 99,03 & 47,16 & 33,33 \\
\hline 4 & Peta Mangrove Konawe 2 & 75,59 & 76,60 & 74,89 & 76,36 \\
\hline 5 & Peta Mangrove Konawe 3 & 0,00 & 79,54 & 78,74 & 29,72 \\
\hline 6 & Peta Mangrove Konawe 4 & 55,36 & 54,48 & 36,42 & 74,30 \\
\hline 7 & Peta Mangrove Konawe 5 & 50,62 & 50,39 & 50,25 & 68,13 \\
\hline 8 & Peta Mangrove Konawe 6 & 11,01 & 18,12 & 10,96 & 14,50 \\
\hline 9 & Peta Mangrove Konawe 7 & 0,00 & 0,00 & 0,00 & 65,53 \\
\hline 10 & Peta Mangrove Kolaka 1 & 0,00 & 82,76 & 76,31 & 90,39 \\
\hline 11 & Peta Mangrove Buton Utara 1 & 86,94 & 86,68 & 72,24 & 76,40 \\
\hline 12 & Peta Mangrove Buton Utara 2 & 89,62 & 87,91 & 84,89 & 76,74 \\
\hline 13 & Peta Mangrove Buton Utara 3 & 68,61 & 89,40 & 90,57 & 20,03 \\
\hline 14 & Peta Mangrove Buton Utara 4 & 98,81 & 95,02 & 89,06 & 77,60 \\
\hline 15 & Peta Mangrove Buton Utara 5 & 93,92 & 93,19 & 58,82 & 70,98 \\
\hline 16 & Peta Mangrove Buton Utara 6 & 92,29 & 79,65 & 81,22 & 91,54 \\
\hline 17 & Peta Mangrove Buton Utara 7 & 36,04 & 60,93 & 44,75 & 38,40 \\
\hline 18 & Peta Mangrove Buton Utara 8 & 18,13 & 19,60 & 19,52 & 29,26 \\
\hline 19 & Peta Mangrove Muna 1 & 95,47 & 92,83 & 93,65 & 93,61 \\
\hline 20 & Peta Mangrove Muna 2 & 89,98 & 89,60 & 88,92 & 80,59 \\
\hline 21 & Peta Mangrove Muna 3 & 66,34 & 98,40 & 97,75 & 99,90 \\
\hline 22 & Peta Mangrove Muna 4 & 63,67 & 61,38 & 98,24 & 72,67 \\
\hline 23 & Peta Mangrove Muna 5 & 94,75 & 94,79 & 95,57 & 88,15 \\
\hline 24 & Peta Mangrove Muna 6 & 65,90 & 94,80 & 93,98 & 75,48 \\
\hline 25 & Peta Mangrove Muna 7 & 89,18 & 89,03 & 86,99 & 78,22 \\
\hline 26 & Peta Mangrove Muna 8 & 79,25 & 74,36 & 72,00 & 91,98 \\
\hline \multirow[t]{3}{*}{27} & Peta Mangrove Muna 9 & 68,01 & 84,30 & 87,45 & 95,46 \\
\hline & Total Hasil Paling Mendekati & 12 & 16 & 14 & 9 \\
\hline & Akurasi Keseluruhan (\%) & 44,44 & 59,26 & 51,85 & 33,33 \\
\hline
\end{tabular}

metode segmentasi $k$-means clustering lebih akurat dalam identifikasi daerah mangrove dibandingkan dengan segmentasi region growing berdasarkan hasil hitung luas daerah mangrove terhadap luas daerah referensi dari LAPAN [12]. Dengan akurasi keseluruhan tersebut, metode $k$-means clustering dan region growing dapat digunakan untuk menghitung luas hutan mangrove menggunak citra satelit Landsat 8, seperti halnya dalam [4], [5].

\section{KESIMPULAN}

Metode segmentasi $k$-means clustering secara keseluruhan menunjukkan identifikasi objek mangrove yang lebih akurat daripada dengan segmentasi region growing, yaitu sebesar 59,26\% dibandingkan 33,33\%. Kedua metode segmentasi citra baik $k$-means clustering maupun region growing dapat digunakan untuk menghitung luas hutan mangrove yang ada di wilayah Sulawesi Tenggara dengan menggunakan data citra satelit Landsat 8.

\section{DAFTAR PUSTAKA}

[1] I. Majid, H. H. I. Al Muhdar, R. Fachur, and I. Syamsuri, "Konservasi Hutan Mangrove di Pesisir Pantai Kota Ternate Terintegrasi dengan
Kurikulum Sekolah,” Bioedukasi, vol. 4, no. 2, pp.488-496, 2016.

[2] M. Vitasari, "Kerentanan Ekosistem Mangrove Terhadap Ancaman Gelombang Ektrim/Abrasi di Kawasan Konservasi Pulau Dua Banten,” Bioedukasi: Jurnal Pendidikan Biologi, vol. 8, no. 2, pp. 33-36, 2015.

[3] Pusat Pemanfaatan Pengindraan Jauh, Pedoman Teknik Pengolahan Data Pengindraan Jauh Landsat 8 untuk Mangrove. Lembaga Penerbangan dan Antariksa Nasional, 2015.

[4] E. T. Opa, “Analisis Perubahan Lahan Mangrove di Kabupaten Pohuwato Propinsi Gorontalo dengan Menggunakan Citra Landsat,” Jurnal Perikanan dan Kelautan Tropis, vol. 6, no. 2, pp. 79-82, 2010.

[5] A. K. S. Manoppo, N. Anggraini, and Y. Marini, "Identifikasi Mangrove dengan Metode Optimum Index Factor (OIF) pada Data SPOT6 dan Landsat 8 di Pulau Lingayan," in Pertemuan Ilmiah Tahunan XX dan Kongres VI MAPIN: Masyarakat Ahli Penginderaan Jauh, Bogor, Indonesia, Feb. 2015.

[6] K. T. Setiawan, N. Aggraini, and A. K. S. Manoppo, "Estimasi Perhitungan Luas Daerah di Pulau-Pulau Kecil Menggunakan data Citra Satelit 
Landsat 8 Studi Kasus: Pulau Pramuka Kepulauan Seribu DKI Jakarta," in Seminar Nasional Pengindraan Jauh, Indonesia, 2016, pp. 294-300.

[7] D. Heksaputra, P. W. Dhina, and S. Nilawati, "Perbaikan Kualitas Citra Iris Mata untuk Pengenalan Pola (Biometric),” Khazanah: Jurnal Mahasiswa, vol. 7, no. 2, pp. 11-23, 2015.

[8] I. A. Kesuma, H. Herman, and M. Munawir, "Penerapan Metode Klaster K-Means pada Segmentasi Warna Citra Digital dengan Pemrograman R”, in Seminar Nasional Inovasi dan Teknologi Informasi, Medan, Indonesia, Nov. 2016, pp. 427-430.

[9] A. Atina, "Segmentasi Citra Paru Menggunakan Metode K-Means Clustering,” Jurnal Pendidikan Fisika dan Keilmuan, vol. 3, no. 2, pp. 57-65, 2017.
[10] F. Kanditami, D. Saepudin, and A. Rizal, "Analisis Contrast Limited Adaptive Histogram Equalization (CLAHE) dan Region Growing dalam Deteksi Gejala Kanker Payudara pada Citra Mammogram,” Jurnal Elektro Unika Atma Jaya, vol. 7, no. 1, pp. 15-28, 2014.

[11] D. P. Agrisativa, "Estimasi Bobot Karkas Sapi Berdasarkan Metode Region Growing dan Klasifikasi K-NN,” Skripsi, Universitas Telkom, Bandung, 2018.

[12] Pusat Pemanfaatan Penginderaan Jauh LAPAN, "Sebaran Perubahan Hutan Mangrove Indonesia Tahun 2016," Oct. 2017. [Online]. Available: http://spbn.pusfatja.lapan.go.id/layers/geonode \%3Amangrove_2014_2016_penyusutan2\#info

[13] E. Prasetyo, Pengolahan Citra Digital dan Aplikasinya Menggunakan MATLAB. Yogyakarta: Penerbit Andi, 2011. 
